\title{
Frederick Andrew Howarth
}

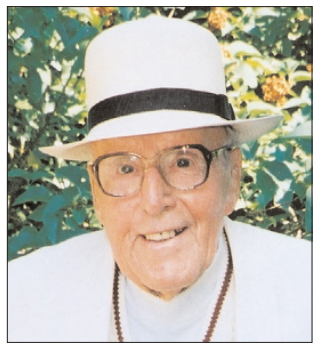

F. Andrew Howarth, a Life Member of the BDA and a former president of the East Lancashire and East Cheshire Branch, died peacefully in Budleigh Salterton Hospital on 16th April 2003, at the age of 101 years.

Born on 29th August 1901 and educated throughout the First World War in a succession of schools in Lancashire and Cheshire, Andrew followed the advice of his great-uncle (a neurologist) who advised him to "Go in for dentistry. That's the coming thing".

Andrew graduated with LDS from the Turner Dental School in 1924 and, as a result of his friendship with the son of the 1923 BDA President, George Cameron, six months postgraduate training was arranged in London, observing and learning from such eminent men as Kelsey Fry and St John Stedman, the latter of whom was the first man in England to practise inferior dental block anaesthesia. He had learnt this technique in America and taught it to Andrew amongst others. A house surgeon appointment in Manchester was followed by an assistantship in St Helens in Lancashire for the princely sum of seven guineas per week. In 1932 he set up a general practice in Wilmslow where he lived and practised for the rest of his professional life. He was made an Honorary Dental Surgeon at Turner Dental School in 1936, acting as a demonstrator to the students, and held this voluntary position for ten years. A member of the BDA since his graduation, he was on the Representative Board for seven years and was made a Life Member in 1970.

\section{Gordon Cowley}

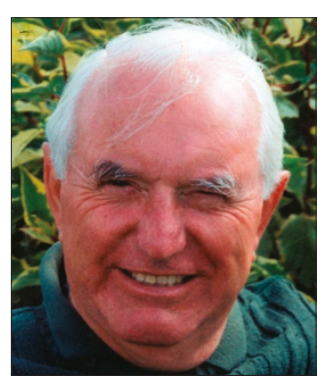

Gordon Cowley died on the 13th February 2003, he was 72. Although born in South Africa, he was brought to England when only three, and has lived in or near Chelmsford, Essex for most of his life since.

He qualified at Guy's in 1953, and after National Service in the RAF and two years in Cambridge as an assistant to Phil Betts, moved back to Chelmsford where he started a single handed practice at 92 Broomfield Road. He was deservedly popular and soon very busy, and grateful for help from his younger brother Ken who joined the practice soon after he qualified, also at Guy's.

At the 1974 shake up of the NHS, Area Dental Officers were created, and Gordon was appointed to this post for Essex. It carried responsibility for the Community Service, as well as a much more vague overseeing of NHS general practice. Much tact and hard work were required, but ADO's were abolished in 1982, and he returned to

\section{Gordon admitted to being 'a child of his}

own time'; he felt a great loyalty to the concept of the National Health Service he was 18 and starting at Guy's when the NHS began.
His enthusiasm for dentistry was unabated to the end of his life and on his centenary, the then BDA President, Dr Peter Swiss remarked that "his crystalclear recall of his entire dental career made for a most memorable afternoon."

His enthusiasm for dentistry was unabated to the end of his life and on his centenary he was visited by the then BDA President, Dr Peter Swiss, who remarked that "his crystal-clear recall of his entire dental career made for a most memorable afternoon".

Andrew's other interests included golf and swimming. He was Captain and President of both East Lancs. and East Cheshire Dental Golf Society and Prestbury Golf Club.

In 1966 he retired and moved to Budleigh Salterton in Devon where he continued to attend the local Branch and Section meetings until, whilst swimming off Budleigh beach, a rogue wave threw him onto the pebbles and damaged his eyesight. A keen Anglican and committed family man, he leaves a daughter, Veronica, four grandchildren and nine great-grandchildren to whom our sympathies are extended on the loss of an exceptional colleague.

Rosemary Longhurst

practice, this time single-handed, back in Chelmsford where he continued until retirement in 1988.

During all his practising life in Essex he was an interested dental politician, serving in all the usual posts including two stints as Branch Secretary and Chairmanship of the Local Dental Committee. He became Branch President in 1985, choosing Brussels for the Branch weekend trip, partly to go to Waterloo where he made an excellent guide to the battlefield.

He was a member of the BDA Representative Board from 1967 to 1981, both as Branch Secretary and as an elected member, and also the GDSC. On retirement, he was elected a Life Member of the BDA.

Dentally speaking, Gordon admitted to being 'a child of his own time'; he felt a great loyalty to the concept of the National Health Service - he was 18 and starting at Guy's when the NHS began. So not only was his practice, I believe, exclusively NHS, no matter whom he was treating, but his political and many other dental activities were devoted to making the system work for the benefit of both patients and dentists. I am sure he regarded this as a return to society of the largely free education he had enjoyed.

In retirement, looking after a series of large gardens and some gentle golf exercised body, and he kept brain alive with historical research and some writing. He was proud of finding new facts and solving a puzzle for a book 'In the wake of captain cook', which he wrote about Charles Clerke, Cook's second in command on his final voyage.

Gordon died after a mercifully short illness, leaving a son and daughter, five grand children, and his wife, Von, to all of whom he was very devoted.

Kit Hughes 